\title{
Modal Sosial Pemimpin Nasional Pasca Pemilu 2004 .
}

\author{
Muhammad Idrus
}

The article below investigates the urgent need of a social capital for national leader, especially in the context of Indonesian leader who chosen after public election 2004 in Indonesia. Social capital in term of psychology constitutes a traits that embedded at individu that forming the values of life, and those of regulations to facilitate a good cooperation. Talking the problem of Indonesian leadership nowadays, the expectation that emeges that leader who chosen by public election April, 5, 2004 is a leader really who characterized by Putnam, honesty and egalitarian who treate himself/ herself as a part of society. Hence, the important of the people of indonesia direct, correct, control their leader so that they return to right way.

\section{Kondisi Sosial Ekonomi Indonesia}

1 erakleitos mencandra bahwa kenyataan itu bersifat pantharei, mengalir dan berubah. Ungkapan klasik tersebut terbukti saat ini, dengan banyaknya perubahan di sekitar kita. Bahkan untuk beberapa negara berkembang isu perubahan menjadi tema yang sengaja dipopulerkan, karena hal tersebut dipahami sebagai suatu usaha untuk meninggalkan keterbelakangan (backwardness).

Dari sini, kemudian dapat pula dipahami, bahwa perubahan itu sesungguhnya tidak akan pernah mencapai satu titik jenuh. Sebab dari segi proses, perubahan menganut logika ongoing process dan ongoing formulation, dan dari segi motivasi, perubahan memuat sasaransasaran yang ingin dicapai secara pasti dan harus senantiasa dalam situasi yang berkelanjutan. Seiring dengan logika di atas, maka dengan sendirinya akan memunculkan keinginan untuk melakukan penyempurnaan pada piranti yang telah dimiliki dalam merencanakan, membangun, mengarahkan, dan memanfaatkan perubahan.Meski begitu, tentunya harus dengan tetap memperhitungkan berbagaj persoalan yang dapat muncul di dalamnya atau berkaitan dengan perubahan yang dilakukan.

Mengaitkan keinginan untuk mengubah sisi kehidupan di masa depan, dalam konteks perubahan kondisi berbangsa salah satunya dibutuhkan sumber daya manusia yang memadai. Pada sisi ini, kita disadarkan betapa situasinya bagi bangsa Indonesia kurang begitu menguntungkan, mengingat untuk saat ini peringkat kualitas sumber daya manusia Indonesia termasuk rendah jika dibandingkan dengan negara-negara di sekitar Asean -Philiphina, Thailand, Malaysia, Brunei dan Singapura- apalagi jika untuk lingkup dunia.

Situasi ini semakin tidak menguntungkan dengan munculnya pelbagai konflik, mulai dari yang sifatnya kelompok kecil hingga bernuansa etnis dan agama, konflik vertikal antara mahasiswa dan TNI. Belum 
lagi dengan șikap dan perilaku yañg ditunjukkan para elit politik yang terkadang menyakiti hati rakyat, -semisal 'mempersoalkan tunjangan akhir jabatan dewan di saat rakyat mengalami kesusahan ekonomiatau ungkapan para pemimpin yang cenderung tidak membuat rakyat tenteram.

Persoalan-persoalan tersebut semakin merapuhkan fundamental perekonomian masyarakat bangsa ini, yang ditandai antara lain dengan :

1. meningkatnya utang luar negeri pemerintah Indonesia, yaitu sebesar 133 milyar dolar (sama dengan emoat kali lipat lebih dari volume anggaran pendapatan dan belanja negara setiap tahun, atau 100 persen lebih dari produk domestik bruto/PDB, dan utang dalam negeri sebesar 600 milyar dolar (Kompas, 11 April 2002);

2. pertumbuhan ekonomi (PDB) Indonesia sebesar $3 \%$, menempati urutan kedua dari bawah, satu tingkat di atas Thailand (Kompas, 11 April 2002);

3. tingkat inflasi yang tinggi;

4. terjadinya ketidakseimbangan antar pedesaan, dan kawasan perkotaan, ekploitasi besar-besaran sumberdaya alam di pedesaan, sehingga menimbulkan dampak eksternal yang menciptakan biaya sosial tinggi.

Menvermati suasana itu, menyadarkan kita untuk memformat ulang model pembangunan yang selama ini dilakukan. Dalam tulisannya Anwar (dalam Rumagit, 2002) mengemukakan bahwa kebijaksanaan yang menyangkut pembangunañ di masa lalu sampai sekarang dianggap hampir identik dengan pemusatan perhatian kepada kebijaksanaan pertumbuhan ekonomi nasional yang menekankan pada akumulasi kapital fisik (phisical capital) yang bersifat sentralistik, dan mengabaikan keterkaitannya dengan kapital-kapital yang lain
- seperti :-11) kāpital alam (nátural capoitàl);

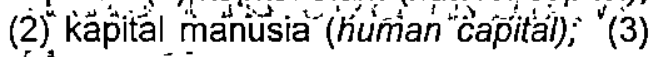
kapital sosial (social capital).

Merujuk pada pendapat yang dikemukakan Anwar di atas, ternyata prosês pembangunan yang hanya menekankan pada satu kapital tertentu menimbulkan banyak terjadinya patologi dalam kẹhidupan sọsial. Watchel (dalam Ancók, 2003) menulis bahwa orientasi ekonomi yang mengacu pada pertumbuhan telah menumbuhkan mental pertumbuhan (growth mentality) yang membuat orang mengakumulasi materi sebanyak-banyaknya, dengan tidak memperdulikan orang lain yang sangat membutuhkan materi tersebut tetapi tidak memperolehnya. Dengan mengambil contoh kasus pada masyarakat Amerika, Watchel menyatakan bahwa kebahagiaan dan kepuasaan hidup selalu berbanding ierbalik dengan akumulasi kekayaan. Makin meningkat jumlah kekayaan materi yang dimiliki, makin meningkat jumlah permasalahan kehidupan, dan makin tidak bahagia kehidupan manusia.

Paparan di atas mengisyaratkan alihalih ingin membangun suatu tatanan ekonomi yang dapat membawa bangsa pada kemajuan dan setara dengan bangsabangsa lain, malah justru menuai krisis multidimensional yang bukan hanya melanda sisi perekonomian saja, tetapj juga menghancurkan pilar-pilar peradaban. Menelaah situasi itu, Chaniago $(2001)$ mengemukakan bahwa kebijakan, ekonomi yang lahir dari lembaga tertinggi negara dan eksekưtif Indonésia mengindikasikan konversi cara berpikir para pemimpin (waktu ituj) menjadi hiper-pragmatis, yaitu melalüi eksploitasi nilai lokasj dan nilai lahan perkotaan, diikuti olể kepađătan pendụdụk kota metroplitan sebagai potensi ekonomi tanpa memperhatikan poblem-problem sosial yang niscaya muncul menyertainya. 
Secara singkat dapat disimpulkan bahwa ketidakseimbangan proporsi pembangunan antar kapital tersebut-kapital alam (natural capital), kapital manusia (human capital), kapital sosial (social capita)memberi kontribusi signifikan bagi lahirnya multikrisis sebagaimana dialami sekarang ini. Bahkan Watchel (dalam Ancok, 2003) menggarisbawahi bahwa orientasi ekonomi sebagaimana digambarkan di atas, hanya akan menghantarkan manusia pada kehancuran.

Tampaknya hal yang mendesak bagi bangsa ini adalah mengubah paradigma pembangunan ekonomi yang selama ini dilakukan. Juniarto (1999) menawarkan digunakannya paradigma modal sosial bagi upaya perubahan pembangunan ekonomi indonesia. Lebih lanjut diungkap Juniarto (1999) paradigma ini tak melulu menggunakan strategi yang rasional seperti yang dicirikan paradigma modernisasi, ketergantungan atau sistem dunia, tetapi juga memfokuskan pada dimensi irasional yang dipercaya akan mendorong kemakmuran bagi rakyat. Strategi pembangunan yang dipilih pun merupakan titik potong antara aliran Neo-Liberalisme yang percaya sepenuhnya pada pasar bebas dan aliran Sosial-Demokrat. Rumagit (2002) dalam analisisnya meyakini bahwa kapital sosial justru yang sangat menentukan keberhasilan proses pembangunan.

\section{Sisi Penting Modal Sosial}

Banyak kalangan memberi definisi tentang istilah modal sosial. Sirrianni, D., \& Friedland, L. (tt) menyatakan bahwa modal sosial merujuk pada tersedianya kepercayaan sosial, norma-norma dan jaringanjaringan yang memungkinkan orang menggambarkan dan memecahkan persoalan yang dihadapi. Cohen dan Prusak (dalam Smith, 2001) mendefinisjkan modal sosial sebagai kumpulan dari hubungan yang aktif di antara manusia: kepercayaan. saling pengertian, dan membagi bersama perilaku dan nilai-nilai yang mengikat para anggotanya dalam sebuah jaringan kerja dan komunitas yang memungkinkan adanya kerjasama.

Sementara itu Fukuyama (dalam Sirrianni, D., \& Friedland, L. ) mendefinisikan modal sosial sebagai serangkaian nilai-nilai atau norma-norma informal yang dimiliki bersama di antara para anggota suatu kelompok masyarakat yang memungkinkan terjalinnya kerjasama di antara mereka. Terkait dengan definisi yang diberikan Fukuyama ini, Ancok (2003) memberi komentar bahwa dari sudut pandang psikologi definisi kapital sosial yang diajukan Fukuyama sebagai sesuatu traits (sifat) yang melekat (embedded) pada diri individu yang berupa tata nilai kehidupan dan aturan yang dianut dan dijalankan oleh individu yang memfasilitasi kerjasama yang baik.

Lebih lanjut diungkap Ancok (2003) bahwa definisi Fukuyama ini terkait dengan nilai yang diajukan oleh Schwartz, yaitu (1) universalim nilai tentang (a) pemahaman terhadap orang lain; (b) apresiasi; (c) toleransi; (d) proteksi terhadap manusia dan makhluk ciptaan Tuhan lainnya; (2) benevolence nilai tentang nilai pemeliharaaan dan peningkatan kesejahteraan orang lain; (3) tradition nilai yang mengandung (a) penghargaan; (b) komitmen; (c) penerimaan terhadap tradisi dan gagasan budaya tradisional; (4) conformity nilai yang terkait dengan pengekangan diri terhadap dorongan dan tindakan yang merugikan orang lain; (5) security nilai yang mengandung (a) keselamatan; (b) keharmonisan; (c) kestabilan masyarakat dalam berhubungan dengan orang lain dan memperlakukan diri sendiri. 
Putnam (1995) dan World Bank (1999) mendefinisikan kapital sosial merujuk pada institusi, hubungan-hubungan dan normanorma yang membentuk kualitas dan kuantitas interaksi sosial masyarakat. Meski demikian Putnam juga menggarisbawahi bahwa kapital sosial bukanlah sekumpulan institusi semata, tetapi merupakan perekat yang menyatukan mereka yang berada di dalamnya.

- Merujuk pada kondisi yang kini tengah terjadi di Indonesia tampaknya makna modal sosial lebih sesuai jika disederhanakan sebagai sebuah faktor sosial budaya, yaitu sebagai sebuah nilai, norma yang memungkinkan terjadinya relasi antar individu, individu dengan institusional atau negara yang membentuk sebuah jaringan kerjasama. Dengan begitu mengacu pada pemaknaan tersebut, maka dimensi dari kapital sosial ini dapat dibagi menjadi tiga, yaitu : (1) dimensi struktural; (2) dimensi kognitif; (3) dimensi relasional. Dimensi struktural mengacu pada pola hubungan antar para pelaku yang saling mempengaruhi dan adanya saling ketergantungan. Dimensi kognitif mengacu pada ketersediaan representasi umum, intepretasi dan minds-set positive. Dimensi terakhir merujuk pada jenis hubungan personal yang dikembangkan melalui interaksi. Terkait dengan retiga dimensi ini adalah tersedianya rasa percaya, empati, sifat amanah, berpikir positif, apresiatif.

Dalam konteks dimensi struktural, saat ini terjadi hilangnya kepercayaan masyarakat terhadap negara, stateless. Jika pada episode sejarah Orde Baru, dimana pengaturan ekonomi daerah dilakukan dari Jakarta, sedangkan daerah-daerah yang berposisi sebagai penyumbang besar bagi peningkatan ekonomi negara, justru hanya mendapat "jatah" yang dianggap tidak sepadan dengan kontribusi mereka pada Jakarta.

Tentunya membangun kapital sosial dalam konteks dimensi struktural ini tidak cukup hanya dengan pembagian jatah sekian persen, yang lebih penting adalah terjadinya proses pendelegasian kepercayaan Jakarta terhadap daerah-daerah. Artinya jika pada masa lalu, begitu dominan dalam hal pengaturan ekonomi dan pemerintahan daerah, maka untuk masa depan peran pemerintah pusat berhenti hanya sebatas pengelola keuangan negara. Dengan begitu, untuk masa mendatang pelibatan daerah dalam proses penentuan perekonomian daerahnya menjadi keharusan, termasuk di dalamnya, misalnya, dalam pembahasan mengenai investasi asing yang akan masuk, berapa besar belanja daerah yang dibutuhkan, bagaimana mengatasi persoalan utang, dan lainnya. Tentu saja kebijakan ini disertai dengan dihapuskannya sentralisasi pengambilan keputusan ekonomi yang hanya berpusat di Jakarta.

Secara psikologis masyarakat akan bergairah untuk melakukan aktivitas pembangunan jika kepada mereka diberi ruang untuk berpartisipasi secara aktif. Memposisikan mereka sebagai subjek pembangunan berarti menumbuhkan rasa percaya pada masyarakat terhadap pemerintahnya. Lebih dari itu, pemerintah telah menghargai sisi kemanusiaan rakyatnya.

Selanjutnya dari sisi dimensi kognitif, maka setiap individu dalam komunitas jaringan tersebut harus memiliki sebuah mental set, atau minds-set positif dalam menghadapi situasi seburuk apapun. Kondisi yang terjadi saat ini tampaknya banyak individu yang kehilangan nalar positif dalam merespon stimulus yang muncul 
dalam kehidupan sosial. Saat ini setiap orang cenderung untuk reaktif-negatif saat masuk dalam sebuah persoalan sosial, prinsip yang kemudian muncul adalah "hantam dulu urusan belakang".

$\therefore$ Dimensi relasional, yaitu mèrujuk pada kemampuan individu dalam menjalin relasi dengan sesama -tanpa melihat sisi' etnis, agama, ras, ' golongan-', individu dengàn - pemerintahannya ataupun dengan institusi. Jika sisi ini dapat terbangun maka konflikkonflik yang muncul sebagai upaya menjelaskan identitas etnisnya dapat -diturunkan tingkat ketegangannya. Lebih dari itu, energi.konflik yang: dimiliki,dapat dialihkan pada upaya memperbaiki citra diri di mata internasional secara lebih baik.

Sebenarnya mengapa kapital sosial ini banyak direkomendasikan para ahli sebagai suatu pendekàtan baru dalam próses perrbangunan sékarang ini. Dảam tulisan' nya Putnam (1995) menegaskan bahwa (1) kapital sosial meimüngkinikan orang untuk memecahkan kembali permasalahan secara lebih mudah; (2) dengan mengibaratkan sebagai pelumas dari sebuah roda; kàpital sosial memberi peluang pada individu untuk membaritu institusi/negara atau pemerintahnya secara lebih halus; (3) dapat mengatasi permasalahan; (3)' modal sosial dapat meningkatkan tali silaturahmi (kekerabatan) atau solidaritas yang-ada dengan mengembangkan rasa kesadaran akan adanya kesalinghubungan nasib di antara sesama (kita); (4) diharapkan kapital sosial dapat mereduksi biaya transaksi. Keempat hal tersebut memberi nilai lebih pada kapital sosial dałam mengatasi satu situasj tertentu.

Adajpun terkait dengan 'sisi perekonomian; Putnam (1995) menunjukkan bükti bahwa pertumbuhan ekonomi: sanggat berkorelași derigañ kehadiran modal sosial.
Pertum̄buhan ekonómi s̃uatú masyarakat akan baik apabila ciri-ciri berikut ini dimiliki oleh masyarakát, yaitu (1) hadirnya hubungan yang erat antar-anggota masyarakat; (2) adanya pemimpin yang jujur dan egaliter yang memperlakukan dirinya sebagai bägian dari masyarakat bukan sebagai penguása; (3) adanya rasa saling percaya dan kerjasama antar unsur masyaakakat. Cólèman (1998) menyatakan bahwä -seçara umum kapital sosial menunjukkan dua karakteristik utama, yaitu (1). mengembangkan beberapa aspek struktur sosial untuk peningkatan efisiensi; (2) memfasilitasi tindakan individu dalam struktur. Forum Report (2003) merekomendasikan bahwa kapital sosial memiliki potensi yang berpengaruh'secara positif terhadap pengembangan kebijakan publik dan membantu kerangka berpikir untuk menjelaskan dan menambahkan jaringan pada wilayah yang tampak begitu berbeda.

\section{Modal Sosial Pemimpin Masa Depan.}

Membicarakañ persoalan pemimpin dalam konteks kekinian untuk situasi Indonesia adälah munculnya harapan agar pemimpin yang dihasilkan proses Pemilu 5 April 2004 adalah pemimpin sebagaimana yang dicirikan oleh Putnam (1995), yaitu pemimpin yang jujur dan dan egaliter yang memperlakukan dirinya sebagai bagian dari masyarakat bukan sebagai penguasa. Selain itu mereka juga harus memiliki beberapa sifat yang mencirikan kapital sosial yang dimiliki seperti : rasa percaya, empati, sifat amanah, berpikir positif, apresiatif. Dengan mengutip pendapat Schwartz, Ancok (2003) menambahkan beberapa sikap seperti mentalitas berkelimpahan, komunikasi transformasional; berorientasi sama-sama puas, sifat melayani.- 
Jujur sepertinya mudah diucapkan, namun tampaknya sulit untuk diaplikasikan dalam kehidupan sosial. Nilai kejujuran mengharuskan orang untuk berbicara sejauh yang diketahui, dalam permasalahan apapun. Namun demikian, dorongan yang muncul pada diri manusia tidaklah selalu positif. Terkadang dalam situasi tertentu individu mencoba menutupi ketidakmampuan dirinya dengan topeng, yang dalam kajian psikologi dikenal dengan istilah "persona".

Fenomena yang terjadi saat dilakukannya pendaftaran bagi' calon legislatif menunjukkan betapa banyak para caleg yang berlakú tidak jujur. Salah satunya diindikasikan dengan adanya penggunaan ijazah palsu. Para caleg tersebut berusaha menggunakan "persona" agar dirinya memperoleh tiket sebagai caleg. Pemimpin semacam ini jelas menengarai ketidakjujuran dirinya, dan harus masuk dalam kelompok "politisi busuk".

Ketidakjujuran pemimpin hanya akan menambah beban penderiataan baik bagi dirinya sendiri, dan tentu saja bagi negara dan masyarakatnya. Jika pemimpin sudah berlaku tidak jujur, maka akan muncul ketidakpercayaan pada birokrasi yang dipimpinnya. Pada ujung-ujungnya sudah dapat diduga, pemerintah yang berjalan di atas ketidakjujuran akan mengailami kehilangar kewibawaan dan menunggu saat kehancurannya.

Sejarah kenabian Muhammad saw membuktikan bahwa dengan mengamalkan rilai kejujuran, seorang mualaf menyadari betapa Islam begitu agung dan menyadarkannya untuk masuk secara utuh dalam Islam. Tentunya kejujuran bukan sebuah teori.yang sekadar enak didiskusikan, tetapi juga memerlukan pengamalan riil. Terlebih bagi para pemimpin yang diberi peluang untuk mengambil peran membuat sejarah bangsa ini.

Sifat kedua yang diajukan Putnam (1995)' adalah pemimpin egaliter yang memperlakukan dirinya sebagai bagian dari masyarakat bukan sebagai penguasa. Sejarah bangsa ini tidak lepas dari nuansa feodal, yang begitu sarat pembedaan antara pemimpin dan yang dipimpin. Meski sudah lebih dari setengah abad merdeka, namun tampaknya suasana feodal masih tampak dalam banyak situasi bermasyarakat dan bernegara:

Merujuk pada sifat yang diajukan Schwartz (dalam Ancok, 2003) yaitu sifat melayani, maka pemimpin egaliter memposisikan dirinya sebagai bagian dari masyarakat bukan sebagai penguasa, dan tentu saja-bukan minta dilayani tetapi melayani kepentingan orang yang dipimpinnya. Dalam banyak situasi pemimpin ini menjadi contoh awal dari setiap kebijakan yang dikeluarkan. Sehingga begitu ironis tatkala didengungkan gerakan hemat dan mengencangkan ikat pinggang, sementara dirinya begitu bebas mengumbar nafsunya. Pemimpin yang demikian itu tidak merasa . dia berada dalam komunitas yang dipimpinnya. Dia tidak pernah menyatakan "kita" tetapi selalu mengungkap "saya" yang mencirikan bahwa dirinya bukanlah bagian dari komunitas masyarakat yang dipimpinnya.

Sesuai dengan jabatannyà, pemimpin dalam setiap struktur órganisasi akan menempati posisi puncak. Selain itu, dari sisi pengambilan kepütusan dialah orang pertama dan orang terakhir sebagai kunci munculnya sebuah kebijakan. Terkait dengan persoalan operasional, maka seorang pemimpin harus memilliki rasa percaya yang tinggi pada bawahannya. Sehingga tatkala telah hilang rasa 
kepercayaan antara pimpinan dengan pelaksana operasional, maka jangan berharap muncul interaksi positif di antara mereka.

Dalam tulisannya Fukuyama (dalam Sirrianni, D., \& Friedland, L., tt) menyatakan pentingnya kepercayaan dalam membentuk modal sosial. Bagi Fukuyama, kepercayaan yang tinggi akan cenderung mengembangkan modal sosial secara lebih besar, dan konsekuensi dari itu adalah pertumbuhan ekonominya juga lebih besar. Pentingnya kepercayaan ini juga dinyatakan Bowles \& Gintis (dalam Ancok, 2003) yang menyatakan bahwa secara umum modal sosial merujuk pada kepercayaan.

Dengan begitu, hadirnya kepercayaan antara pimpinan dan orang yang dipimpin, serta pemimpin yang dapat dipercaya (amanah) mutlak diperlukan untuk membangun suatu modal sosial yang lebih besar. Dengan semakin besarnya modal sosial yang dimiliki satu komunitas, artinya semakin kuatnya ikatan kekerabatan dalam satu komunitas, maka seluruh jaringan kerjasama yang dibangun dalam komunitas tersebut akan berjalan sebagaimana yang diharapkan.

Berpikir positif dan jernih dalam menghadapi individu atau persoalan merupakan salah satu sifat yang dibutuhkan untuk membangun modal sosial bagi seorang pemimpin. Kerap dijumpai dalam kehidupan bermasyarakat ada seorang pemimpin yang cepat mengambil suatu simpulan, padahal yang bersangkutan belum memahami situasi yang sebenarnya, maka dapat diduga yang terjadi adalah penyelesaian yang tidak menyelesaikan masalah.

Seorang pemimpin dituntut untuk selalu berpikir positif (husnudzan) terhadap orang lain. Manakala ada sebuah perilaku seseorang yang mungkin kurang menyenangkan bagi dirinya, maka sang pemimpin hendaklah tidak serta merta menyalahkannya. Cara yang terbaik adalah dengan berusaha untuk memahami mengapa. seseorang berperilaku demikian.

Dalam konteks berpikir positif juga terkait sifat tidak mencurigai seseorang dengan perasaan yang berlebih. Dalam kajian psikologi rasa curiga dan tidak percaya kepada orang lain tanpa adanya alasan kerap diistilahkan sebagai paranoid. Jika seorang pemimpin memiliki sifat dan sikap semacam itu, maka interaksi antar orang-orang yang dipimpinnya juga berlangsung dengan penuh rasa curiga. Akibatnya sudah dapat diduga, organisasi tersebut akan berjalan disharmonis.

Berpikir positif juga termasuk didalamnya berusaha untuk memahami orang lain, dan bukan sekadar mewajibkan orang lain memahami dirinya sendiri. Sejarah membuktikan bahwa banyak pemimpin yang terobsesi dengan kekuasaannya dan lupa bahwa ada orang lain di sekitarnya. Merasa dirinya besar, kerap pemimpin tidak mau mendengar apa yang dikatakan oleh orang-orang di sekitarnya, atau dalam mendengar memilih siapa yang berbicara, bukan apa'yang dikatakan -undzur ma qala wala tandzur man qala-

Membangun sebuah modal kapital dibutuhkan rasa empati dari pimpinan. Pemimpin harus dapat menunjukkan sikap merasakan apa yang sedang dirasakan oleh mereka yang dipimpinnya. Fenomena di masyarakat saat ini muncul gejala "SMOS" yaitu Senang Melihat Orang lain Susah, dan Susah Melihat Orang lain Senang. Gejala ini muncul dalam banyak situasi berinteraksi antarindividu. 
Seharusnya sikap yang dibangun adalah Senang Melihat Orang lain Senang, dan Susah Melihat Orang lain Susah. Inilah sikap empati yang harus ditunjukkan seorang pemimpin. Jadi meskipun yang bersangkutan adalah lawan politiknya sekalipun, tapi tatkala lawannya itu mendapat kesusahsn, maka dia harus juga dapat merasakan rasa susah yang diderita lawan politiknya. Hal ini memang sulit dilakukan, apalagi jika dalam diri individu telah tertanam perasaan tidak senang.

Seorang pemimpin harus dapat merasakan segala kesusahan orang yang dipimpinnya. Seperti yang telah diungkap di atas, seorang pemimpin hendaknya dapat merasakan kesusahan saat terjadinya krisis ekonomi yang dirasakan rakyatnya, bukan lalu menghina perasaan dan melukai hati rakyat dengan cara misalnya mempersoalkan hak-hak pesangon sebelum lengser dari jabatannya.

Merujuk pada sejarah rasulullah, beliau pernah menyatakan bahwa beliau adalah orang pertama yang akan merasakan lapar manakala rakyatnya mengalami kelaparan, dan sebaliknya menjadi orang yang terakhir kenyang saat rakyat hidup makmur. Ironisnya saat ini situasi tersebut dibalik, biar rakyat menderita asalkan pemimpin tidak mengalaminya. Dengan begitu keinginan para anggota dewan yang tjdak mengambil uang pesangon patut dihargai dan dicontoh oleh para anggota dewan lainnya, bukan lalu .seperti sekarang ini mereka yang tidak mau menerima justru seperti disisihkan, dan dianggap invarian.

Sikap apresiatif pemimpin ditunjukkan dengan adanya penghargaan terhadap usaha dan pekerjaan yang telah dilakukan para bawahannya. Sikap apresiatif ini akan mendorong para bawahan untuk bekerja dengan optimal, karena mereka merasa ada penghargaan atas karya yang mereka hasilkan. Lebih dari itu sikap apresiatif merupakan manifestasi penghargaan kepada para bawahan, inilah yang akan menjadikan para bawahan loyal terhadap atasannya.

Hanya saja fenomena yang terjadi secara empiris adalah kurangnya sikap apresiatif para pimpinan terhadap hasil kerja para bawahannya. Para pemimpin lebih kerap memberi hukuman, sanksi ataupun ungkapan kemarahan lainnya dibanding memberi pujian. Kerap terjadi bawahan dimarahi hanya disebabkan satu kesalahan kecil yang dibuatnya, sementara saat yang bersangkutan berprestasi dia tidak mendapatkan pujian ataupun penghargaan yang layak.

Memerintah memang menjadi hak para pimpinan, dan menjalankan perintah atasan sudah menjadi kewajiban bagi para bawahannya. Dalam konsep modal sosial, tentunya ada cara berbeda bagi atasan untuk memerintah bawahannya. Artinya, tidak perlu bawahan diperintah dengan ungkapan-ungkapan yang meskipun dia melaksanakan perintah itu namun dilakukannya dengan perasaan yang kurang senang. Para pimpinan perlu memilih cara berbeda saat memerintah, misalnya dengan mengucapkan permintaan tolong. Saat bawahan telah melaksanakan perintah itu, maka menjadi kewajiban pimpinan mengucapkan terima kasih atas usaha yang dilakukan para bawahannya. Untuk itu sudah selayaknya para pemimpin terbiasa untuk mengucapkan kata "minta tolong", "maaf" dan "terima kasih" kepada para bawahannya.

Mentalitas berkelimpahan (abudance mentality) menurut Schwartz (dalam Ancok, 2003) adalah sifat kepribadian yang suka membagi apa yang dimilikinya kepada or- 
ang lain. Dengan membagi atau memberikan apa yang dimilikinya kepada orang lain, akan menjadikan orang tersebut justru semakin kaya. Pemimpin masa depan hendaknya memiliki sifat berkelimpahan ini, memberi apa yang dimilikinya pada bangsa dan negara, dan bukan sebaliknya menggerogoti kekayaan negara dengan cara menjual dan mengatasnamakan dirinya.

Mentalitas berkelimpahan ini perlu dibangun dan disosialisasikan kepada seluruh komponen bangsa, agar tidak lagi banyak dijumpai kaum gelandangan dan pengemis di jalan-jalan. Sejarah panjang Indonesia kerap menemukan pejabatpejabat yang justru memperkaya dirinya sendiri dengan cara korupsi, kolusi ataupun membangun jaringan keluarga di lembaganya. Masa depan membutuhkan pemimpin yang tidak pelit dan tidak rakus terhadap harta.

Kepribadian lain yang harus dimiliki sebagai seorang pemimpin masa depan adalah kemampuan komunikasi transformasional. Ancok (2003) menjelaskan bahwa kemampuan transformasional ini adalah kemampuan seseorang untuk selalu memilih kata-kata yang enak didengar telinga dalam berbicara dengan orang lain. Bila terjadi perbedaan dengan orang lain, dia tetap memilih kata-kata yang menyejukkan hati dan pikiran dalam menanggapi perbedaan tersebut.

Menarik menyimak acara dialog antara séorang menteri kabinet pembangunan dengan salah seorang wakil LSM (Lembaga Swadaya Masyarakat) yang diselenggarakan salah satu televisi swasta. Dalam tayangan tersebut, sang menteri begitu kesal dengan kalimat-kalimat yang diucapkan oleh lawan bicaranya, dengan serta merta mendorong lawan bicaranya. Adegan tersebut memang hanya sekilas, dan tampaknya tidak banyak yang menyorotinya. Meski demikian, hal itu telah menunjukkan pada seluruh masyarakat bahwa sang menteri tersebut tidak dapat memilih kalimat-kalimat bijak, sehingga lebih menyukai mempergunakan dorongan fisik tatkala terpojokkan oleh lawan bicaranya.

Ironisnya, saat diwawancarai wartawan dengan santainya sang menteri tersebut berkomentar "menteri kok takut". Ungkapan ini jelas bukan ungkapan arif yang seharusnya keluar dari seorang menteri. Setidaknya rakyat dapat menganggap bahwa yang bersangkutan tidak mampu melakukan komunikasi transformasional.

Penggalan cerita di atas hanyalah satu dari sekian peristiwa tentang ketersinggungan pejabat, dan tentunya sejarah mencatat banyak peristiwa lain yang tidak terungkap media. Biasanya ketidakmampuan melakukan komunikasi transformasional ini akan dibarengi sikap agresif baik secara verbal ataupun fisik. Tentunya harapan masyarakat bangsa ini adalah siapapun yang akan menjadi pemimpin, yang bersangkutan harus dapat berbicara yang menyejukkan hati.

Dalam konsep hastabrata kepemimpinan, salah satu sifat pemimpin diibaratkan seperti unsur-unsur alam, misalnya tanah untuk melambangkan kesabaran dan kelegaan hati, angin (udara) untuk mempersonifikasikan șifat adil sang pemimpin, dapat mendengar aśpirasi màsyarakat yang dipimpinnya, air yang bermakna pemimpin selalu berusaha mencari cara untuk selalu dekat dengan para bawahannya. Namun pemimpin juga dilambangkan dengan perlambang api, sebagai sifat kewibawaan.

Sifat lain yang harus dimiliki seorang pemimpin adalah berorientasi sama-sama puas (win-win). Pemimpin yang memiliki 
sifat ini akan berusaha untuk membuat orang lain gembira dan dia juga gembira setiap berinteraksi dengan bawahannya. Pada kenyataannya banyak ditemui bawahan yang selalu susah saat berinteraksi dengan para pemimpinnya, stress saat harus berhadapan muka dengan pemimpinnya..

Gagasan akhir dari Pemilu 2004 adalah terpilihnya para pemimpin yang lebih mengerti dan memahami rakyatnya. Pemimpin yang dapat membawa masyarakat bangsa ini menuju kejayaan sebagaimana dicita-citakan saat negara ini didirikan. Tentu saja bagi mereka yang berlaga di ajang bursa kepemimpinan tingkat nasional ini harus memiliki banyak persyaratan, selain kapital intelektual maka kapital sosial menjadi salah satu syarat yang perlu dikedepankan.

Meski demikian Ancok (2003) juga mengingatkan bahwa modal sosial juga memiliki sisi negatif, yaitu tatkala modal sosial ini dimiliki oleh kelompok manusia yang tidak bermoral. Selain itu sisi fanatisme yang mendiskriminasi kelompok lain juga merupakan sisi negatif modal sosial. Gejala ini tampaknya mulai muncul dengan selalu didengung-dengungkannya putra daerah pada setiap pemilihan pejabat daerah. Jika benar begitu, patut pula dipertanyakan jangan-jangan konsep otonomi daerah justru menjadi pemicu lemahnya modal sosial bangsa ini.

- Menutup tulisan ini, penulis ingin mengutip sebuah sabda dari baginda rasul, yaitu "kama takununa yuwala "alaikum". Sabda yang kurang lebih bermakna, "bagaimana keadaan kalian, demikianlah pula ditetapkan penguasa atas kalian". Shihab (1994) memaknai sabda tersebut dengan kalimat (1) seorang penguasa atau pemimpin adalah cerminan dari keadaan masyarakatnya; (2) suatu pesan untuk tidak tergesa-gesa menyalahkan terlebih dahulu pemimpin yang menyeleweng, durhaka atau membangkang, karena pada hakikatnya yang bersalah adalah masyarakat itu sendiri, sebab bukankah pemimpin atau penguasa itu adalah cermin keadaan masyarakat itu sendiri?

Bak pepatah menepuk air didulang, terpecik muka sendiri, kita bermaksud menyalahkan para pemimpin kita, sebenarnya kita membuka aib kita sendiri. Disinilah pentingnya masyarkat membuat koreksi atas pemimpinnya, menegur mereka dan kembali mengarahkan mereka ke arah yang benar. Tentu saja paket pertama adalah memilih mereka yang memang layak dan mampu untuk menjadj pemimpin kita, sebab bukankah pemimpin itu adalah cermin diri kita sendiri?

\section{Daftar Pustaka}

Ancok, J. (2003). "Modal Sosial dan Kualitas Masyarakat." Pidato Pengukuhan Jabatan Guru Besar pada Fakultas Psikologi Universitas Gadjah Mada. Yogyakarta.

Damar Juniarto 1999. Wajah Ekonomi Indonesia Baru: Dilarang Berekonomi. http://www.bubu.com/kampus/mei99/ fokus3.htm

Forum Report. (2003). " The Policy Implications Of Social Capital.". Forum Report No. 28 May 2003. Dublin: The National Economic And Social Forum

Kompas, 11 April 2002

Kompas, 17 September 2001

Rumagit, G.A.J., (2002). Alternatif Model Pembangunan Ekonomi Indonesia 
Modal Sosial Pemimpin Nasional Pasca Pemilu 2004, Muhammad Idrus

Menghadapi Era Globalisasi: Suatu Kajian Empiris. Retrieved from World Wide Web http://rudyt.tripod.com/ sem2_012/grace_rumagit.htm 17 Maret 2004.

Shihab, M.Q., 1994. Lentera Hati: Kisah dan Hikah Kehidupan. Bandıng: Mizan -

Sirrianni, D., \& Friedland, L. (tt). Social Capital. Retrieved from World Wide Web http://www.cpn.org/tools/dictionary/ capital.html. 18 Maret 2004.
Smith, M. K. 2001, 'Social Capital', the encyclopedia of informal education. www.infed.org/biblio/social_ capital.htm. 25 Maret 2004.

World Bank (1999). What is Capital Social? Retrieved from:http://www, worldbank. org/poverty/scapital/whatsc.htm. 17. Maret 2004. 